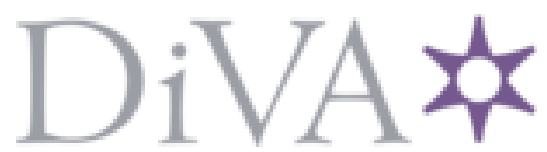

http://www.diva-portal.org

\title{
Postprint
}

This is the accepted version of a paper published in Futures: The journal of policy, planning and futures studies. This paper has been peer-reviewed but does not include the final publisher proof-corrections or journal pagination.

Citation for the original published paper (version of record):

Ojala, M. (2017)

Hope and anticipation in education for a sustainable future

Futures: The journal of policy, planning and futures studies, 94: 76-84

https://doi.org/10.1016/j.futures.2016.10.004

Access to the published version may require subscription.

N.B. When citing this work, cite the original published paper.

Permanent link to this version:

http://urn.kb.se/resolve?urn=urn:nbn:se:oru:diva-53272 
Hope and anticipation in education for a sustainable future

\author{
Maria Ojala
}

Uppsala University

Örebro University

Accepted version of article published in Futures

The final definitive version of this article has been published: Please refer to:

Ojala, M. (2017). Hope and anticipation in educating for a sustainable future. Futures, 94, 7684.

The published article can be found at: https://doi.org/10.1016/j.futures.2016.10.004

(C) $<2019>$. This manuscript version is made available under the CC-BY-NC-ND 4.0 license http://creativecommons.org/licenses/by-nc-nd/4.0/

Address correspondence to Maria Ojala, Department of Education, Box 2136, Uppsala University, 75002 Uppsala, Sweden; Phone: +46 18 4712422; e-mail: maria.ojala@oru.se.

The writing of the article has been supported by The Swedish Research Council Formas under Grant 2010-1152 to the author 


\begin{abstract}
Global sustainability problems pose serious challenges for humanity. In handling these problems education for sustainable development (ESD) is seen as important. Different key competences that ESD should focus on have been introduced, such as the ability to deal with future dimensions. Still, studies indicate that future dimensions are not always included in ESD and that many young people are pessimistic concerning the global future. Therefore, one could argue that a focus on anticipatory emotions, especially hope, should be included in ESD. There is a worry, however, that hope will lead to unrealistic optimism and/or less engagement. The aim of this paper is to problematize the discussion about hope in relation to ESD and the global future by grounding it in theories from different disciplines and in empirical research about young people, hope, and climate change. The review shows that hope is a complex, multifaceted, and sometimes contested concept. Hope can be related to denial, but in other cases it can help people face and do something constructive with their worries about the global future. The close relation between hope and trust is emphasized and a need for critical emotional awareness in ESD is argued for.
\end{abstract}




\section{Hope and anticipation in education for a sustainable future}

\section{Introduction}

We live in a world characterized by various global sustainability problems, such as climate change, poverty, and loss of biodiversity, that pose serious challenges for humanity. In dealing with these problems education for sustainable development (ESD) is seen as an important long-term solution, and the need to prepare students for societal change is emphasized (UNESCO 2014; UN 2015). Various key competences that ESD should focus on have been put forward, such as the ability to deal with future dimensions, that is, anticipatory competence, and the ability to deal with ethical questions, that is, normative competence (Wiek, Withycombe, \& Redman, 2011). Not least, educational researchers have pointed to the importance of helping students to handle the 'wicked' character of these problems/challenges: the uncertainty, ambiguity, and complexity that are inherent parts of them (Barth, Godemann, Rieckmann, \& Stoltenberg, 2007; de Haan, 2006; Lotz-Sistika, Wals, Kronlid, \& McGarry, 2015; Rieckmann, 2012). Still, studies indicate that although many young people show an interest in the global future, feelings of helplessness or even hopelessness are quite common (Connell, Fien, Lee, Sykes, \& Yencken 1999; Nordensvaard 2014; Strife, 2012; Threadgold, 2012; Tucci, Mitchell, \& Goddard, 2007). Therefore, one could argue that a specific focus on anticipatory emotions, and perhaps especially hope, should be included in ESD (Hicks, 2014; Ojala, 2012; Stevenson \& Peterson, 2015; Wals, 2015).

Lurking behind the pleas for a focus on hope in ESD, however, is a worry that hope is just an illusion, a feel-good emotion that will lead to unrealistic optimism and/or even less engagement around these issues, thereby preserving the status quo (for reviews of this view about hope see for instance Levitas, 1990 and Zaleski, 1994). In the ESD research field studies that focus on change, transformative learning, and the political dimension of education seldom mention hope, even though the importance of other emotional aspects, such as 
passions and dissonance, are brought up (see for instance Lotz Sistika et al., 2015; Sund \& Öhman, 2014; Wals, 2007). The concept of hope is instead included in research about factors that promote or hinders private-sphere pro-environmental behavior (Hornsey \& Fielding, 2016; Ojala, 2015; Stevenson \& Peterson, 2015) and political engagement within the current system, such as voting (Ojala, 2015). However, can hope also play an important role in transformative learning, in an ESD that helps students face and actively deal with change? Unfortunately, there is not much work in this research field that deals with hope in a more thorough theoretical fashion.

The aim of this paper is to deepen, broaden, and problematize the discussion about hope in relation to ESD and the global future. A specific focus will be on transformative learning that prepares students for societal change. The discussion will be grounded both in theories about hope from disparate scientific disciplines and in empirical research about young people's hope concerning global climate change, perhaps the most urgent of all sustainability challenges. Although practical implications for ESD will be elaborated on to a certain extent, it will for example be argued that in order for hope to promote transformative learning there is a need to strike a balance between a critical emotional awareness in ESD and creating trustful relationships, the intention is not to give pre-packaged solutions to how hope can be included in ESD, that is, to instrumentalize hope. Instead, the thought behind this paper is that it is only by gaining combined theoretical and practical insights into how hope works that educators can transform this concept into practice in concrete educational settings.

\section{Future dimensions in ESD}

Future dimensions are firmly embedded in the concept of ESD through the Brundtland Commission's definition of sustainable development as "development that meets the needs of the present without compromising the ability of future generations to meet their own needs" (WCED 1987, p. 43). This includes both envisaging alternative and preferable futures and to 
anticipate and prevent future negative developments and consequences of global sustainability problems/challenges (see Wiek et al., 2011). The need for 'change' and 'transformation' of the current societal order has been emphasized at the highest level in recent years through, for example, two UN documents about the global goals for sustainable development and the global action program on education for sustainable development (UNESCO 2014; UN 2015). The question then is how to work concretely with future dimensions in ESD.

Researchers have identified anticipatory thinking as one key competence that ESD ought to promote (Barth et al., 2007; De Haan, 2006; Wiek et al., 2011). In this regard, it is vital to acknowledge that the conceptualizations of 'sustainability competence' in the ESD field vary from more deterministic ones to more holistic ones. However, the most common view seems to be to perceive sustainability competence as a holistic, contextual, relational, and emergent thing (Wals, 2015) — emergent in the sense that we cannot tell for sure what a sustainable future should look like; we can only tell what is unsustainable today. Hence, what seems to be in focus when discussing sustainability competences is: "the complex combination of knowledge, skills, understandings, values, and purposes" (Biesta, 2015, p. 676-677).

Anticipatory thinking in the ESD field is, for instance, about the capability to think in a forward-looking way and to acknowledge and deal with uncertainty in a constructive way (Wals \& Swartzinger, 2012). This is in accordance with the broader anticipatory literature, in which the ability to deal with complexity and uncertainty is seen as pivotal (Miller, 2010; Poli, 2010). Wiek and colleagues (2011, p. 207) define anticipatory competence as “...the ability to collectively analyze, evaluate, and craft rich 'pictures' of the future related to sustainability issues and sustainability problem-solving frameworks.” Anticipatory competence is closely related to other ESD competencies, such as normative competence, which involves taking ethical dimensions into account when discussing and envisioning preferable and more sustainable futures (Wiek et al., 2011). It is also related to strategic 
competence, for instance the ability to find realistic pathways to these futures. In a study with ESD experts, Rieckmann (2012) found that future dimensions such as anticipatory skills, skills to achieve change, and empowerment strategies, as well as competency to cope with ambiguity, frustration, and uncertainty related to these future dimensions were mentioned frequently in relation to ESD practice. Thus, according to researchers and experts, the future and the complexity connected to it ought to be an important part of ESD.

Torbjörnsson and Molin (2015) have shown, however, that future dimensions are not a common topic in schools, at least not in Swedish schools, when students are asked if they have learned about the future (see also Hicks, 2002). In addition, many studies performed in different countries indicate that people are quite pessimistic about the global future, particularly when it comes to environmental problems such as climate change (Connell et al. 1999; Hicks, 2002; Nordensvaard, 2014; Strife, 2012; Threadgold, 2012; Tucci et al., 2007). Therefore, one could argue that emotional aspects, especially anticipatory emotions of hope and worry, ought to be specific parts of ESD. This view is supported by a study showing that students in higher education saw one important aspect that they would like to focus on in ESD as being how to deal with the worrisome and sometimes even depressing aspects of global problems in a hopeful manner (Gardiner \& Rieckmann, 2015). These students wanted to learn more about how to deal with worry and how to promote hope. Hence, critical emotional awareness, including hope, could be seen as an important additional competence to promote in ESD (Ojala, 2013).

If one thinks that hope ought to be included in ESD, it is important to pinpoint what hope is. In the coming sections I will first define what hope is from a psychological perspective, where hope is seen as consisting of cognitive, emotional, and action components (Lazarus, 1991; Snyder, 2000). I will then broaden the focus to include views about hope from other 
disciplines in relation to societal issues and from empirical studies with young people about hope in relation to global climate change.

\section{Psychological theories on hope}

The emotion theorist and psychologist Lazarus included both cognitive and emotional aspects in his definition of hope. He saw hope as an emotion that is related to a cognitive appraisal of wishing for a desired goal to come true even though the odds are not greatly in favor of it (Lazarus, 1991, p. 282). Thus, his conception of hope is closely associated with uncertainty, and this aspect is what makes it different from optimism. The emotion of hope demands only the perception that a desirable goal is possible to reach to be evoked (Miceli \& Castelfranchi, 2010). Lazarus also perceived hope as a way to cope with negative situations and states (Lazarus, 1991). Without difficulties there is no need for hope. Furthermore, hope has to be actively cultivated in order to constructively deal with these difficulties (see Folkman, 2010). Hence, according to this view hope is a positive feeling about the future that is evoked by positive, albeit uncertain, beliefs about desired goals and active coping in the face of hardships. Still, both in health science (see Snyder, Rand, King, Feldman, \& Woodward [2002] for a review) and social science (see Levitas, 1990; Zaleski, 1994 for a review), hope has quite often been seen as a double-edged sword. Although it could be a psychological relief from a harsh reality, it has also been perceived as a way to escape this reality and the responsibility to take action.

In order to solve the problem of inaction, which is sometimes related to hope, Snyder (2000) created a theory that connected hope firmly to action components. In this theory the cognitive part of hope is seen as comprising three different aspects: (1) a positive future goal - that which we want to happen, (2) pathway thinking - to find ways to reach the desired goal, and (3) agency thinking - to motivate oneself to use these pathways (Snyder, Rand, \& Sigmon, 2001). People high on hope have the ability to clearly conceptualize their goals, to 
change these goals if needed, and to generate alternative paths to their goals, especially if an initial path is blocked (Snyder et al. 2001). They also increase their motivation through agency thinking. In addition, the emotional part of the concept of hope is seen as giving strength to act even if there are no certainties (McGeer, 2008; Snyder, 2000).

However, the psychologists mentioned above did not develop their theories in relation to societal problem and the global future; they focused solely on more private, mainly healthrelated, problems, and the future at an individual level. It could be argued that for hope to work in a transformative way in relation to global sustainability challenges all three of the hope dimensions described above (goals, pathways, agency) need to be taken into account; but, at the same time, the concept of hope also needs to be broadened. In the following sections of the paper these dimensions will be related, on the one hand, to theories about hope concerning societal problems and, on the other hand, to empirical studies about how young people go about evoking hope in relation to climate change.

\section{Existential hope}

In contrast with the hope theories already mentioned, which perceive goals as very important parts of this concept, in a review of theories about hope, Webb (2007) identifies ways of looking at hope that do not include goal-setting, that is, that have a more open stance toward the future. In this section I will focus on one of these, existential hope, and in the next section I will focus on another, critical hope.

Hope is quite often seen as being existential in character; it is a way of being, a way of life (Zaleski, 1994). In this regard, people do not have clear goals that evoke hope, but hope is instead based in 'basic trust' in oneself, others, and the basic goodness of existence (Webb, 2007). It is a hope that everything will work out fine in the end, although there is no guarantee. This way of hoping is also found in relation to climate change. It is quite common among different age groups of young people to claim that they harbor hope concerning 
climate change because they put trust in the ingenuity of humanity, and that 'we' will eventually find a way to solve the problems (Ojala, 2012). Some young also claim that you simply need to be hopeful; otherwise there is no point in doing anything.

At first glance this kind of existential hope could be perceived as shallow, almost as a form of wishful thinking. However, it is quite common among more critical and societyoriented hope scholars to see it as a necessary base for more evolved forms of hope. According to Zimmerman, the philosopher Bloch saw the existence of existential anxiety in the human condition as making it necessary to develop a hope strategy in order to "accept, endure, resist, and withstand it" (see Zimmerman, 2013, p. 246). In critical pedagogy Freire also perceived hope as an ontological necessity: "We succumb to fatalism, and then it becomes impossible to muster the strength we absolutely need for a fierce struggle that will re-create the world. I am hopeful, not out of mere stubbornness, but out of an existential concrete imperative" (Freire, 1992, p.8). However, although Freire saw this kind of hope as an absolute must, he also was very clear that it is not enough, at least not to transform an unjust society.

\section{Critical hope}

Webb (2007) distinguishes another form of hope that is not based in positive goals, but differs from existential hope in that it is grounded in reality and the material world, namely critical hope. Here hope is seen as a negation of the negative. Both Bloch and Freire saw hope foremost as based in an acknowledgment and a critical understanding of the current situation; in a realization that something is missing (Freire, 1992; see also Levitas, 1990). Hope is born out of a lack that leads to a longing/hunger, and the hope process can be started, for instance, by disrupting practices, that is, showing concretely that things can be otherwise (Daly, 2013; McManus, 2003). Webb claims, concerning critical hope: “Hope's positive glow offers here no comforting refuge but rather stimulates a restless protest against present suffering" (Webb, 
2007, p. 71). Hope is stimulated by a vision of that the present needs to be, and can be, changed, and that there is a promise of a future which is 'Not-Yet.' Or to put it in Freire's words, behind every obstacle lies an untested feasibility (Freire, 1992). Thus, in critical hope, the future is open.

In relation to this kind of hope Braithwaite (2004) and Ojala (2007) have argued that hope as a positive feeling is intrinsically related to negative feelings of worry or even pessimism (see also Hornsey \& Fielding, 2016 and Saunders \& Jenkins, 2012). It is by accepting the problems at hand, for instance the threat from climate change, and by facing and bearing the negative emotions related to them that a hope can be evoked that will drive engagement. Ojala $(2007,2008)$ has shown through empirical studies with young people that a dialectical relation between hope and worry concerning global problem seems to motivate pro-environmental actions. This is a way of coping with climate change among young people that is called cognitive restructuring, or positive re-appraisal, in which the young perceive the problem but are able to switch the perspective and also see more positive aspects, for instance that at least our society's knowledge about climate change has increased (Ojala, 2012). This way of coping is mainly used in a pro-active way to activate hope, instead of in a reactive way, trying to dispel worry. This is in harmony with the view of the psychologist Satterfield (2000), who argues that hope is most mature when combined with integrative complexity, that is, the capacity to ponder about the complexity of problems, seeing them from multiple perspectives.

To constantly switch perspectives, however, is both cognitively and emotionally demanding, and far from all young people do this. Instead of facing their worry about climate change, they avoid it by using distancing and distracting strategies (Ojala, 2012; Pettersson, 2014). Or they evoke hope by de-emphasizing, or even denying, the seriousness of the problem. They claim for instance that they feel hopeful because the climate problem is 
exaggerated in the media, or that the problem does not concern them personally since the negative effects will only be visible in a faraway future. But there are also some young people that instead get stuck in pessimism by 'hyperactivating' their worries, ruminating about the possibility that everything will get worse, that humanity deserves what is coming, and so on (Ojala, 2012). Both this hope based in denial and this rigid pessimism can be seen as ways of escaping responsibility to act to try to change the situation. Are there any other forms of hope, then, that can promote engagement?

\section{Utopian goal-oriented hope}

In his review of hope, Webb (2007) identifies utopian hope as a goal-oriented kind of hope that is based on desires for alternative collective futures. Webb mentions Rorty as a proponent of this kind of hope (Rorty, 1999). For Rorty, politics is about striving to promote social hope for that which might become real. The imagination of this preferable and alternative future is what stimulates people to act even though the odds are not always in favor of this outcome. In utopian hope, the goals are supposed to be exactly that, utopian, in the sense of not necessarily being realistic. Beckert (2013) even claims that a main driving force for our neo-liberal society is fictional expectations, that is, mental representations of positive future states that are based not on probability calculations, since complexity defies these guesses, but on utopian visions. He further claims that power in society is to a large extent based on who has the means to control these visions.

How then do young people perceive the global future - do they feel hope because of utopian collective visions? What studies have shown is that many young people have either a very bleak picture of the global future (Hicks, 1996, 2002; Threadgold, 2012), or they have underdeveloped views of it (Torbjörnsson \& Molin, 2015). If they have positive views, they are mainly based on techno-optimistic visions where new technological innovations will solve the climate problem (Byrne, Ideland, Malmberg, \& Gracea, 2014; Fløttum, Dahl, \& Rivenes, 
2016; Pettersson, 2011). Therefore, it has been emphasized by educational researchers such as Hicks (2014) that at the same time as educators need to acknowledge and discuss the often dark views of the global future, the 'probable futures,' they also need to help young people to imagine alternative 'preferable futures.' However, although an important aim is that these wished-for futures should be utopian, the need to discuss power relations and ethical issues when working with these issues has been put forward (Bateman, 2015; Wiek et al., 2011). A future that is desirable for one person is not necessarily desirable for another person, and who should decide which of these futures one should strive for? Furthermore, not all wished-for futures are ethical. These aspects point towards the need to ground desirable futures in reality and in discussions about value conflicts.

\section{Pathways to hope or semi-realistic hope}

In order to promote constructive hope, Hicks (2014) argues that it is also vital to compare the 'probable' with the 'preferable' and come up with materially grounded and realistic 'possible' futures. Unrealistic hope could backfire and lead to disengagement and cynicism. Therefore, it is important to combine utopian and critical perspectives and "create images of what could be possible while exploring and documenting the actual limits imposed by the current system" (Burton, 1983, p. 67). This thinking is in accordance with psychological research building on the 'fantasy realization theory' showing that for active engagement to occur the discrepant cognitive aspects of the desired future, on the one hand, and the negative present reality, on the other, have to be elaborated on in a thorough fashion through mental contrasting (Oettingen, 2012). An additional demand is that the relation between the desired future and the here-and-now that is created by this mental contrasting is about the negative reality 'standing in the way' of the desired future.

In addition, Arbuthnott (2010) contends that people are more inclined to engage with futures thinking when they can perceive tangible changes and positive outcomes from their 
involvement. This requires quite concrete goals as well as perceived pathways to reach these goals. In this regard, Amsler (2015) argues that acknowledging that there are alternatives out there is essential but not sufficient for critical forms of hope; there is also a need to discuss and develop paths and infrastructure for societal transformation.

What pathways to hope concerning climate change do young people perceive? Many young people claim that they feel hopeful because there are things that they themselves can do to fight climate change (Ojala, 2012; Pettersson, 2014). These things are highly individualized, however; they are about small things that young people can do in their everyday life, more or less in isolation. Concrete collective engagement as a pathway to a better future seems not to be common among young people today. However, some give voice to collective hope dimensions through thinking that if we all together (including oneself) do things in everyday life, there is hope concerning climate change (Ojala, 2012).

Collective dimensions are also visible in trust as a pathway to climate-change hope, that is, trust in other actors, such as scientists, politicians, and environmental organizations (Ojala, 2012; Pettersson, 2014). The close relation between hope and trust has for example been emphasized in philosophy by McGeer (2008) and in theoretical psychology by Miceli and Castelfranchi (2010). According to them what is specific about hope when compared to other future oriented concepts is that hope includes a trust in forces that are more or less beyond one's control, it is about confronting the limitations of one's agency.

Hope based in trust is however not the opposite of individual and collective engagement; in relation to climate change, hope based in trust seems to give young people the strength to act in the face of uncertainty and hardship (Ojala, 2007, 2015). According to the psychological attachment theory, trust in others is a prerequisite for trust in one's own capability (Ainsworth, 1989). This could be particularly true when it comes to societal 
problems, in which one most probably needs to feel that others are also taking on responsibility in order to feel that it is worthwhile to do anything oneself.

\section{Hope and agency through thinking and practice}

Although some pathways to a more sustainable future are to a certain extent beyond an individual's control and require that one can rely on other actors to take their responsibility, we are all more or less part of the climate problem through our life-styles and everyday choices. Laypeople can be a part of the strivings for a more sustainable society as individuals, for instance as conscious consumers, but also as citizens and by taking active part in different interest groups and organizations. In this regard, Snyder's view of the importance of the agency part of the hope concept comes in focus (Snyder, 2001). According to Snyder people high on hope have the ability to motivate themselves to use identified pathways to a desirable goal.

Zimmerman (2010) refers to Bloch when he argues that educated hope, a hope that leads to engagement for societal change, does not come about automatically but has to be learned and practiced. This includes both success and failure. Related to this, the social psychologist Bandura underlines the importance of self-efficacy, that is, beliefs that one can execute a course of action efficiently, and outcome expectancy, that is, beliefs that these actions will have an effect on for instance the ability to reach a desired goal, in promoting active engagement among people (Bandura, 1997). Self-efficacy is foremost promoted by mastery experiences, which is about concretely devoting oneself to optimal challenging actions and to succeed in mastering them (Bandura, 1997). In this regard, it is vital to have support from others. A sense of agency can also increase by seeing others succeed in performing challenging tasks. Snyder, for his part, emphasized the importance of 'agency thinking,' that is, self-talk that gives motivational strength (Snyder, 2001). 
Proponents of theories about prefigurative politics claim in the same manner that criticism is not enough to transform unsustainable systems into sustainable futures; one also needs to act and, in an experimental way, realize one's political ideals in the present (Amsler, 2015; North, 2011). North argues in relation to climate change that in prefigurative politics people are "...showing through their personal actions what is possible... and thereby inviting curiosity from others who might well make the same changes" (North, 2011, p. 1592). By demonstrating that other ways of being are possible, a sense of agency and hope are evoked.

Studies with young volunteers in environmental and global justice organizations also show that their active engagement is an important source of hope (Ojala, 2007). Again the link to trust seems to be strong. Hope is evoked by the trust found in the companionship of other volunteers and by feeling a sense of belonging to a larger community of active people. With many people doing things together and supporting each other, hope furthermore becomes embodied and the sense of agency increases (see also Johnson, Johnson-Pynn, Sweeney, \&Williams, 2009).

Another way that the agency aspect of hope is part of young people's everyday life is how they deal with ambivalence related to living in a sustainable manner; or to put it in Snyder's hope terms, what their 'agency thinking' looks like (Snyder, 2001). Ambivalence could be seen as a normal response to the complexity and uncertainty related to proenvironmental behaviors, such as recycling and energy saving (Castro, Garrido, Reis, \& Menezes, 2009; Ojala \& Rikner, 2010). However, in a study with young adults the ambivalence they felt in relation to energy saving in the household was handled in different ways by those who did not save energy and those who were ambivalent but nevertheless saved energy (Ojala \& Rikner, 2010). The reluctant energy savers used defensive strategies to cope with their ambivalence, strategies that closed down the cognitive system and that in a theoretical sense can be seen as amplifying feelings of helplessness and powerlessness. These 
strategies were, for instance, overgeneralization and black-and-white thinking. The regular energy savers, in contrast, used strategies that opened up the cognitive system for critical reflection, such as claiming that you at least can be a role model for others or that even small life-style changes at an aggregated level will lead to change, thereby increasing a sense of agency, and subsequently hope. They acted in spite of their ambivalence (Ojala \& Rikner, 2010). Thus, by coping with ambivalence in relation to everyday pro-environmental behavior in different ways, the young either stifled agency or were able to feel agency and hope alongside their ambivalence.

\section{Critical emotional awareness and trust in ESD}

I will end by reflecting in a more direct fashion on what practical implications this review of hope studies could have. How can it enrich the ESD field as well as the new field of anticipation? Based on the theoretical and empirical review, hope can be perceived as consisting of existential, cognitive (goals, pathways, agency thinking), emotional, and action components. However, what has not been in specific focus thus far is that what goals one considers desirable, what pathways one perceives as effective to reach these goals, and if one has the ability to motivate oneself to use these pathways or not, are not cognitions created in isolation but are socially embedded components. Thus, the emotional part of the hope concept, the positive feeling of hope that is evoked by these cognitions, and the related action component, are also social in character. In this regard, Ahmed (2010), although she primarily focuses on happiness, has put forward that there are emotion norms in society about what objects/goals will bring happiness to people in the future and that these desired goals, and pathways to reach these goals, are not politically innocent but are drenched in power dimensions and attempts to govern people. This could be even more true for hope because it is very hard for a person to manage without hope. As an existential concept, hope is an absolute must that people cannot do without (Freire, 1992; Zaleski, 1994). Hence, it could be very 
tempting to use hope as a governing tool (see Ahmed, 2010). Therefore, in this section I will contend that if hope is to work in a transformative way in relation to ESD, critical emotional awareness, including a critical stance towards hope, is vital, but this critical stance need to be combined with trust.

First, this review shows that hope, in both a theoretical and an empirical sense, is a multifaceted and sometimes even contested concept. Even in relation to a rather well-defined problem such as climate change, and experienced by a relatively narrow group, young people living mainly in Northern Europe, hope can be based in different sources and have different functions for different people. Hope also relates differently to engagement. Although the emotional part of hope often works as a temporary relief from harsh reality and the negative emotions related to it (see Lazarus, 1991), its more evolved functions can vary from denial of the seriousness of the climate problem, and thereby also denial of any responsibility to take action, to a constructive way of facing the problem and the negative emotions related to it, thereby motivating action despite uncertainty and hardships (Ojala, 2015).

One example of hope as a contested concept is that most theories of hope would not perceive hope based on denial as real hope. Still, when young people are asked about what gives them hope in the face of climate change, some do base their hope in different ways of de-emphasizing this problem (Ojala, 2012; Pettersson, 2014). The sources of hope in relation to climate change also vary from concrete, often individualized, actions to a capability of switching perspectives to mere existential trust (Ojala, 2012). Thus, it could be argued that it is vital for educators to critically examine and ponder one's own hope-desirable goals and pathways to/sources of hope-since the way educators look at the future could influence hope among their students (Hermans, 2015; Ojala, 2015). In addition, it is vital to encourage critical discussions around these aspects in the classroom. For instance, why do so many young people focus solely on individualized consumer behaviors as pathways to a hoped-for 
sustainable future? Amsler (2011) describes a critical affective pedagogy that aims for an understanding of why one experiences certain desires and not others and includes a critical awareness of how 'power' steers people's deepest desires and emotions, that is, sees emotions as discursive practices. Thus, it could be argued that it is only by making these implicit aspects more visible that transformative learning can be promoted.

Second, the review has shown that the positive emotion of hope, on the one hand, and critical thinking, disruption and transgression, on the other hand, are not necessarily opposites. Authors such as McManus (2003) and Daly (2010), referring to Bloch, argue instead that it is only by disrupting the present that transformative hope can be evoked. However, what is important to realize is that when the order of things is ruptured, when norms are disrupted and transgressed, but also when the existentially challenging aspects with societal problem such as climate change are touched upon, negative emotions are often evoked. These emotions are not pleasant to feel, and we all have more or less habitual ways of dealing with them, coping strategies, including ways of hoping, that sometimes counteract transformation and engagement. Both students and teachers can feel hope because they deemphasize the seriousness of the problem, they can distance themselves from negative emotions felt, hyperactivate their worries, and so on (Ojala, 2012; Hermans, 2016; Pettersson, 2014). Therefore, critical emotional awareness in relation to ESD requires more than verbalizing and critically discussing different emotions, such as various sources of, and pathways to, hope; it also requires knowledge about different more or less habitual ways of coping with negative emotions. For instance, educators can challenge and disrupt less sustainable strategies by presenting alternative ways of coping, for example, cognitive restructuring/positive re-appraisal in dealing with the complexity of climate change and the more positive ways of coping with ambivalence in relation to pro-environmental actions (see 
Ojala, 2012; Ojala \& Rikner, 2010). Different coping strategies can then be compared and discussed critically in the classroom.

Third, as has been shown in the review, hope is either perceived as being open to the future or as based in concrete visions and goals. Proponents of the Blochian way of looking at hope as springing from that which is 'Not-Yet,' a future that is impossible to visualize beforehand, put forward the importance of not closing down the future, of not colonizing it and narrowing down the inbuilt possibilities in the present (McManus, 2003). Other theoreticians instead emphasize the importance of concrete goal-setting for the motivating feeling of hope to occur (Lazarus, 1991; Rorty, 1999; Snyder et al., 2001). In relation to ESD, I would like to suggest a third alternative that takes into account psychological research about emotions. Perhaps a temporary closing of the future, helping students concretely envision 'desirable' futures and then, through critical discussions, transform them into a 'possible' futures (see Hicks, 2014) is a way to reach a longstanding openness toward the future. When people perceive that a concrete positive goal is within reach, positive feelings-for instance the emotional part of hope, excitement, and joy_can be evoked (see Lazarus, 1991; Snyder, 2000). Here, it is vital with an awareness that positive emotions such as these have been found to broaden people's perception of reality, making them more creative and open-minded (Fredrickson, 2001; Fredrickson \& Branigan, 2005; Fredrickson \& Joiner, 2002). This can help them anticipate the future in a more open way and come up with new ideas. In addition, these emotions can buffer anxiety, helping people to face and bear the grim reality of, for instance, climate change (Folkman, 2010). By being able to face anxiety and the problems behind it, a starting point is created for experiencing the lack and the hunger that keep people open to new ways of anticipating the future and that lead to a craving for more hope (McManus, 2003; Daly, 2010). Thus, it could be contended that educators need to facilitate 
this dialectical process between positive and negative emotions in different ways (see also Oettingen, 2012).

The above-mentioned way of hoping is quite demanding, however, and one could argue that hope needs to be based in something more stable than this constant moving between closure, and openness, worry, and hope. Thus, I will end this article by reflecting on the relation between hope and trust. As is obvious from the review of the various hope theories, hope often is based in different dimensions of trust. Trust is a multifaceted concept that is relational, built on a view of the human as a profoundly social being. It is about oneself in relation to others, that is, individual others or collective others, such as groups (Flanagan, 2003). The essence of this concept is a belief in the goodwill of these others and existence in itself, a belief that, just like beliefs related to hope, is related to uncertainty (McGeer, 2008). Trust is born out of concrete experiences of interacting with others (Ainsworth, 1989; Flanagan, 2003).

In relation to ESD, Wals argues that a certain degree of social cohesion, a kind of interpersonal trust, is necessary for transformative learning to take place (Wals, 2007, 2015). This way of emphasizing the importance of social cohesion does not mean that diversity should be stifled — quite the opposite. Trust can instead help people face and respect a diversity of standpoints and conflicting views about sustainability and the future. In this way, disruption and transgression of habitual ways of being and acting become possible, and a seed of hope is planted. The task for educators, thus, becomes to ponder how to facilitate social cohesion and trust in the ESD classroom. In this regard, Fielding (2014) put forward the importance of promoting friendship and 'democratic fellowship' in the classroom, while Keating (2013) emphasizes everyone's radical interconnectedness and use a 'pedagogy of invitation' when she practices transformative learning. As Keating writes: "Pedagogies of 
invitation are nonoppositional. They employ relational teaching tactics that invite and evoke but do not impose change on students.” (Keating, 2013, p. 183).

\section{Conclusion}

This review of theories and empirical studies about hope in relation to climate change has shown that it is a multifaceted concept consisting of existential, emotional, cognitive, and action components, and that it serves different functions and is based in different sources. If hope is seen as an important part of ESD, this complexity needs to be taken into account. In order for hope to promote transformative ESD, educators need to strike a balance between a critical emotional awareness and a trustful atmosphere in the learning setting. Hope is a positive emotion and an existential must that needs to be cultivated, by showing that another way of being is possible, by encouraging trustful relationships and by giving young people the opportunity to concretely work together for change. But since hope also contains cognitive elements and functions as a way to cope with difficulties and negative emotions, critical emotional awareness also is a pivotal part of ESD. Different views of desirable futures and pathways to reach these future goals need to be critically discussed in the classroom. It could also be argued that disrupting unsustainable habits, norms, and practices is not enough for transformative learning to take place; one also needs critical awareness and disruption of 'unsustainable' ways of regulating emotions. 


\section{References}

Ahmed, S. (2010). The promise of happiness. Duke University Press.

Ainsworth, M. D. S. (1989). Attachment beyond infancy. American Psychologist, 44, 709716.

Amsler, S. (2011). From 'therapeutic' to political education: the centrality of affective sensibility in critical pedagogy. Critical Studies in Education, 52(1), 47-63.

Amsler, S. (2015). The education of radical democracy. London \& New York: Routledge.

Arbuthnott, K.D. (2010). Taking the long view: Environmental sustainability and delay of gratification. Analyses of Social Issues and Public Policy, 10, 4-22.

Bandura, A. (1997). Self-efficacy: The exercise of control. New York: Freeman \& Company.

Barth, M., Godemann, J., Rieckmann, M., \& Stoltenberg, U. (2007). Developing key competencies for sustainable development in higher education. International Journal of Sustainability in Higher Education, 8(4), 416-430.

Bateman, D. (2015). Teaching futures in schools. Futures, 71, 122-131.

Beckert, J. (2013). Imagined Futures. Fictional Expectations in the Economy. Theory and Society 42, 219-240.

Biesta, G. (2015). Teaching, teacher education, and the humanities: Reconsidering education as a Geisteswissenschaft. Educational Theory, 65(6), 665-679.

Braithwaite, J. (2004). Emancipation and hope. The Annals of the American Academy of Political and Social Science, 592, 79-98.

Burton, M. (1983). Understanding mental health services: Theory and practice. Critical Social Policy, 7, 54-74.

Byrne, J., Ideland, M., Malmberg, C., \& Gracea, M. (2014).Climate Change and Everyday Life: Repertoires children use to negotiate a socio-scientific issue. International Journal of Science Education, 36 (9), 1491-1509. 
Castro, P. Garrido, M., Reis, E., Menezes, J. (2009). Ambivalence and conservation behaviour: An exploratory study on the recycling of metal cans. Journal of Environmental Psychology, 29, 24-33

Conell, S., Fien, J., Lee, J., Sykes, H., \& Yencken, D. (1999). 'If It Doesn't Directly Affect You, You Don't Think About It': a qualitative study of young people's environmental attitudes in two Australian cities. Environmental Education Research, 5(1), 95-114.

Daly, F. (2013). The zero-point: Encountering the dark emptiness of nothingness. In P. Thompson, \& S. Zizek (Eds.), The privatization of hope: Ernst Bloch and the future of utopia (pp. 164-202). Duke University Press: London.

Fielding, M. (2014). Democratic fellowship and the practice of human possibility. In R. Marples, J. Suissa, \& C. Winstanely (Eds.), Education, Philosophy, and Wellbeing: New Perspective on the Work of John White (pp.54-69). London: Routledge.

Flanagan, C. (2003). Trust, Identity, and Civic Hope. Applied Developmental Science, 7, 165 171.

Fløttum, K., Dahl, T., \& Rivenes, V. (2016). Young Norwegians and their views on climate change and the future: findings from a climate concerned and oil-rich nation. Journal of Youth Studies, Online First.

Folkman S. (2010). Stress, coping, and hope. Psychooncology, 19(9), 901-908.

Fredrickson, B. (2001). The role of positive emotions in positive psychology: The broaden-and-build theory of positive emotions. American Psychologist, 56(3) 218226.

Fredrickson, B., \& Branigan, C. (2005). Positive emotions broaden the scope of attention and thought-action repertoires. Cognition \& Emotion, 19(3), 313-332.

Fredrickson, B., \& Joiner, T. (2002). Positive emotions trigger upward spirals toward emotional well-being. Psychological Science, 13(2), 172-175. 
Freire, P. (1992). Pedagogy of hope. New York: The Continuum Publishing Company.

Gardiner, S., \& Rieckmann, M. (2015). Pedagogies of preparedness: Use of reflective journals in the operationalization and development of anticipatory competence, Sustainability, 7(8), 10554-10575

de Haan G (2006) The BLK '21' programme in Germany: a 'Gestaltungskompetenz'-based model for education for sustainable development. Environmental Education Research, 12(1), 19-32.

Hermans, M. (2016). Geography teachers and climate change: Emotions about consequences, coping strategies, and views on mitigation. International Journal of Environmental and Science Education, 11(4), 389-408.

Hicks, D. (1996). A lesson for the future. Young people's hopes and fears for tomorrow. Futures 28(1), 1-13.

Hicks, D. (2002). Lessons for the future: The missing dimension in education. Oxford: Trifford Publishing.

Hicks, D. (2014). Educating for hope in trubbeled times. Climate change and the transition to a post-carbon future. London: Trentham Books.

Hornsey, M.J., \& Fielding, K.S. (2016). A cautionary note about messages of hope: Focusing on progress in reducing carbon emissions weakens mitigation motivation. Global Environmental Change, 39, 26-34

Johnson, L. R., Johnson-Pynn, J. S., Sweeney, S. S., \& Williams, C. T. (2009). Youth Civic Action: Going Green, Going Global. Ecopsychology, 1(2): 75-84.

Keating, A. L. (2013). Transformation now! Toward a post-oppositional political theory of change. Chicago: University of Illinois Press.

Lazarus, R. S. (1991). Emotion and Adaptation. New York: Oxford University Press. 
Levitas, R. (1990). Educated Hope: Ernst Bloch on Abstract and Concrete Utopia. Utopian Studies, 1(2), 13 - 26

Lotz-Sistika, H., Wals, A.E.J., Kronlid, D., \& McGarry, G. (2015). Transformative, transgressive social learning: rethinking higher education pedagogy in times of systemic global dysfunction. Current Opinion in Environmental Sustainability, 16, 73-80.

McGeer, V. (2008). Trust, hope, and empowerment. Australian Journal of Philosophy, 86(2), $237-254$

McManus, S. (2003). Fabricating the Future: Becoming Bloch's Utopians. Utopian Studies, $14(2), 1-22$.

Miceli, M., \& Castelfranchi, C. (2010). Hope The Power of Wish and Possibility. Theory \& Psychology, 20(2), 251-276.

Miller, R. (2007). Futures literacy: A hybrid strategic scenario method. Futures, 39(4), 341362.

Nordensvaard, J. (2014). Dystopia and Dysutopia: Hope and Hopelessness in German Pupil's Future Narratives, Journal of Edcucational Change, 15, 443-465.

North, P. (2011). The politics of climate activism in the UK: a social movement analysis. Environment and Planning A, 43, 1581-1598.

Oettingen, G. (2012). Future thought and behaviour change. European Review of Social Psychology, 23, 1-63.

Ohman, J., \& Ohman, M. (2013). Participatory approach in practice: An analysis of student discussions about climate change. Environmental Education Research, 19(3), 324-341.

Ojala, M. (2007). Confronting macrosocial worries. Worry about environmental problems and 
proactive coping among a group of young volunteers. Futures, 39(6), 729-745.

Ojala, M. (2008). Recycling and ambivalence: Quantitative and qualitative analyses of household recycling among young adults. Environment and Behavior, 40(6), 777-797.

Ojala, M. (2012). Regulating worry, promoting hope: How do children, adolescents, and young adults cope with climate change? International Journal of Environmental and Science Education, 7(4), 537-561.

Ojala, M. (2013). Emotional awareness: On the importance of including emotional aspects in education for sustainable development (ESD). Journal of Education for Sustainable Development, 7(2), 162-182.

Ojala, M. (2015). Hope in the face of climate change: Associations with environmental engagement and student perceptions of teachers' emotion communication style and future orientation. Journal of Environmental Education, 46(3), 133-148.

Ojala, M. \& Rikner, A. (2010). Att hantera det ambivalenta. Unga vuxnas attityder och beteende gällande energieffektivisering $i$ hemmet. Report No. 66. Örebro, Örebro University: Centre for Urban and Regional Studies.

Pettersson, A. (2014). “De som inte kan simma kommer nog att dö!” En studie om barns tankar och känslor rörande klimatförändringarna. Uppsala Universitet, Forskarskolan i Geografi. Uppsala, Sweden.

Poli, R. (2010). An Introduction to the Ontology of Anticipation. Futures, 42(7), 769-776.

Rieckman, M. (2012). Future-oriented higher education: Which key competencies should be fostered through university teaching and learning? Futures, 44(2), 127-135.

Rorty, R. (1999). Philosophy and Social Hope. London: Penguin.

Satterfield, J. M. (2000). Optimism, culture and history: The roles of explanatory styles, integrative complexity, and pessimistic rumination. In J. E. Gillham (Ed.), The science of optimism and hope (pp. 349-378). Philadelphia: Templeton Foundation Press. 
Saunders, A., \& Jenkins, S. (2012). 'Absent fear': Re-envisioning a future geography. Futures, 44, 494-503.

Snyder, C. R. (2000). Genesis: The birth and growth of hope. In C. R. Snyder (Ed.), Handbook of Hope (pp. 25-38). San Diego, CA: Academic Press.

Snyder, C.R., Rand, L.K., King, E.A., Feldman, D.B., \& Woodward, J.T. (2002). "False" hope. Journal of Clinical Psychology, 58(9), 1003-1022.

Snyder, C.R., Rand, K.L., \& Sigmon, D. R. (2001). Hope Theory. A Member of the Positive Psychology Family. In C. R. Snyder \& S. J. Lopez (Eds.), Handbook of Positive Psychology (pp. 257-275). New York: Oxford University Press.

Stevenson, K., \& Peterson, P. (2015). Motivating Action through Fostering Climate Change Hope and Concern and Avoiding Despair among Adolescents. Sustainability, 8(1).

Strife, S. J. (2012). Children's environmental concerns: Expressing Ecophobia. The Journal of Environmental Education, 43, 37-54.

Sund, L. \& Öhman, J. (2014). On the need to repoliticise environmental and sustainability education: rethinking the post-political consensus. Environmental Education Research, 20(5), 639-659.

Threadgold, S. (2012). "I reckon my life will be easy, but my kids will be buggered”: ambivalence in young people's positive perceptions of individual futures and their visions of environmental collapse. Journal of Youth Studies, 5, 17-32.

Torbjörnsson, T, \& Molin, L. (2015) In school we have no time for the future: voices of Swedish upper secondary school students' about solidarity and the future. International Research in Geographical and Environmental Education, 24(4), 338-354.

Tucci, J., Mitchell, J., \& Goddard, C. (2007). Children's fears, hopes and heroes: Modern childhood in Australia. Melbourne, Australia: Australian Childhood Foundation. UN (2015). Transforming our world: the 2030 Agenda for sustainable development. United 
Nations General Assembly.

UNESCO (2014). Roadmap for implementing the global action programme on education for sustainable development. Paris: UNESCO.

Wals, A.E.J. (2007). Learning in a Changing World and Changing in a Learning World: Reflexively fumbling towards sustainability. Southern African Journal of Environmental Education, 22, 35-45.

Wals, A. E. J. (2015). Beyond unreasonable doubt. Education and learning for socioecological sustainabiltity in the antropocene. Wageningen University, Wageningen, The Netherlands.

Wals, A.E.J., \& Schwarzin, L. (2012). Fostering organizational sustainability through dialogic interaction. The Learning Organization, 19(1), 11-27.

WCED, World Commission on Environment and Development (1987). Our Common Future. Oxford: Oxford University Press.

Webb, D. (2007). Modes of hoping. History of the human sciences, 20(3), 65-83.

Wiek, A., Withycombe, L.,\&, Redman, C. L. (2011). Key competencies in sustainability: A reference framework for academic program development. Sustainability Science, 6(2), $203-218$

Zaleski, Z. (1994). Personal future in hope and anxiety perspective. In Z. Zaleski (Ed.), Psychology of future orientation (pp. 174-194). Lublin: Towarzystwo Naukowe KUL.

Zimmerman, R.E. (2013). Transforming utopian into metopian systems: Bloch's principle of hope revisited. In P. Thompson, \& S. Zizek (Eds.), The privatization of hope: Ernst Bloch and the future of utopia (pp. 246-268). London: Duke University Press. 